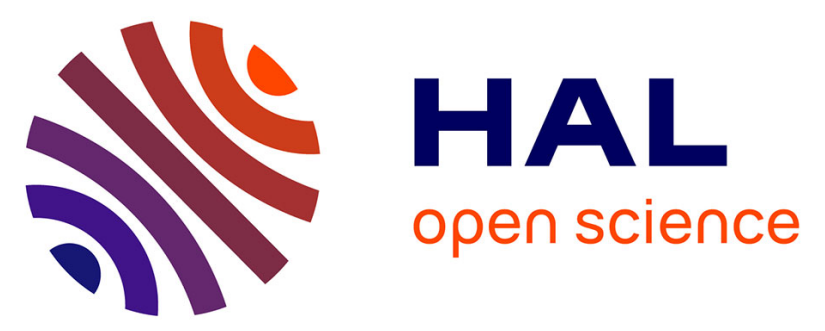

\title{
Cyclic shear zone cataclasis and sintering during lava dome extrusion: Insights from Chaos Crags, Lassen Volcanic Center (USA)
}

Amy G. Ryan, Michael J. Heap, James K. Russell, Lori A. Kennedy, Michael Clynne

\section{To cite this version:}

Amy G. Ryan, Michael J. Heap, James K. Russell, Lori A. Kennedy, Michael Clynne. Cyclic shear zone cataclasis and sintering during lava dome extrusion: Insights from Chaos Crags, Lassen Volcanic Center (USA). Journal of Volcanology and Geothermal Research, 2020, 401, pp.106935. 10.1016/j.jvolgeores.2020.106935 . insu-03093680

\section{HAL Id: insu-03093680 https://hal-insu.archives-ouvertes.fr/insu-03093680}

Submitted on 4 Jan 2021

HAL is a multi-disciplinary open access archive for the deposit and dissemination of scientific research documents, whether they are published or not. The documents may come from teaching and research institutions in France or abroad, or from public or private research centers.
L'archive ouverte pluridisciplinaire HAL, est destinée au dépôt et à la diffusion de documents scientifiques de niveau recherche, publiés ou non, émanant des établissements d'enseignement et de recherche français ou étrangers, des laboratoires publics ou privés. 


\section{Journal Pre-proof}

Cyclic shear zone cataclasis and sintering during lava dome extrusion: Insights from Chaos Crags, Lassen Volcanic Center (USA)

Amy G. Ryan, Michael J. Heap, James K. Russell, Lori A. Kennedy, Michael A. Clynne

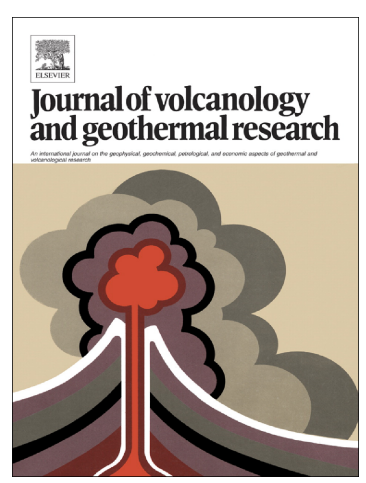

PII: $\quad$ S0377-0273(20)30192-X

DOI: $\quad$ https://doi.org/10.1016/j.jvolgeores.2020.106935

Reference: $\quad$ VOLGEO 106935

To appear in: Journal of Volcanology and Geothermal Research

Received date: $\quad 5$ April 2020

Revised date: $\quad 17$ May 2020

Accepted date: $\quad 22$ May 2020

Please cite this article as: A.G. Ryan, M.J. Heap, J.K. Russell, et al., Cyclic shear zone cataclasis and sintering during lava dome extrusion: Insights from Chaos Crags, Lassen Volcanic Center (USA), Journal of Volcanology and Geothermal Research (2018), https://doi.org/10.1016/j.jvolgeores.2020.106935

This is a PDF file of an article that has undergone enhancements after acceptance, such as the addition of a cover page and metadata, and formatting for readability, but it is not yet the definitive version of record. This version will undergo additional copyediting, typesetting and review before it is published in its final form, but we are providing this version to give early visibility of the article. Please note that, during the production process, errors may be discovered which could affect the content, and all legal disclaimers that apply to the journal pertain.

(C) 2018 Published by Elsevier. 
Cyclic shear zone cataclasis and sintering during lava dome extrusion: Insights from Chaos Crags, Lassen Volcanic Center (USA)

Amy G. Ryan ${ }^{1 *}$, Michael J. Heap ${ }^{2}$, James K. Russell ${ }^{1}$, Lori A. Kennedy ${ }^{1}$ and Michael A. Clynne ${ }^{3}$

${ }^{1}$ Department of Earth, Ocean and Atmospheric Sciences, University of British Columbia, 20202207 Main Mall, Vancouver BC V6T 1Z4, Canada

${ }^{2}$ Université de Strasbourg, CNRS, Institut de Physique de Globe de Strasbourg UMR 7516, F67000 Strasbourg, France

${ }^{3}$ United States Geological Survey, Volcano Science Center, 345 Middlefield Road MS 910, Menlo Park CA 94025, United States

* Corresponding author: Amy G. Ryan (aryan@eoas.ubc.ca; +1 778302 2331).

Journal of Volcanology and Geothermal Research

MS \#: VOLGEO_2020_124

Submitted: April 5, 2020

Revised: May 15, 2020

\section{Highlights:}

- A syn-eruptive shear zone (gouge and cataclasites) envelopes Dome $\mathrm{C}$ at Chaos Crags

- Shear zone cataclasites have lost porosity and lithified by solid-state sintering

- Magma ascent rates $<10 \mathrm{~m} / \mathrm{d}$ are required to form observed cataclasites

- Shear zone permeability loss and strengthening hinder outgassing and magma ascent

- Cyclic fracturing and sintering can dictate lava extrusion vs. explosivity

Keywords: solid-state sintering; lithification; densification; ascent-rate; permeability; strength 


\begin{abstract}
The ascent and extrusion of crystal-rich magma is commonly facilitated by deformation partitioned within annular, conduit-parallel shear zones. The physical properties and textures of the shear zone materials, where exposed at surface, provide a record of ascent and eruption dynamics. We describe the shear zone developed in Dome C, part of Chaos Crags in the Lassen Volcanic Center (California, USA). The extruded shear zone comprises volcanic fault gouge and variably densified cataclasites. The competent cataclasites evidence deep-seated gouge production followed by gouge densification within the conduit on the timescale of lava dome ascent. Textural, geochemical and mineralogical data identify solid-state sintering as the densification mechanism. At the temperatures and pressures in the volcanic conduit, solid-state sintering causes rapid porosity and permeability loss within the gouge and concomitant material strengthening. Longer dwell times (i.e., slower ascent) allow for more sintering, producing stronger, denser and less permeable cataclasites. At Chaos Crags, we use the extent of sintering, quantified by residual porosity, to recover minimum in-conduit dwell times necessary to produce the observed cataclasites. Our analysis of the Dome $\mathrm{C}$ cataclasites suggests a maximum linear ascent rate of $10 \mathrm{~m} / \mathrm{d}$ and a minimum ascent time of 100 days. We evaluate the consequences of shear zone lithification by solid-state sintering for the eruption of other crystal-rich, glass-poor magmas. Chaos Crags cataclasites preserve evidence of multiple cycles of fracturing, cataclasis and (re-)sintering suggesting a mechanism for transitions between effusive and explosive phases of dome-building eruptions.
\end{abstract}




\section{Introduction}

The rate at which magma transits the crust has a strong influence on the magma's physical, chemical and transport properties, and can control the nature of eruption and the eruption products (Rutherford, 2008). Slow ascent rates can induce decompression-driven degassing and crystallization causing increases in magma viscosity and resulting in the formation of lava domes (Nakada et al., 1995b; Sparks, 1997; Voight et al., 1999; Sparks et al., 2000; Edmonds and Herd, 2007; Rutherford, 2008; Cashman et al., 2008; Husain et al., 2014). During particularly slow ascent of intermediate magmas (e.g., extrusion rates $<7 \mathrm{~m}^{3} / \mathrm{s}$; Watts et al., 2002), extensive degassing and crystallization create strong, stiff magmas that favor brittle deformation rather than viscous flow (Sparks et al., 2000; Hale and Wadge, 2008; Pallister et al., 2008; Heap et al., 2016; Zorn et al., 2018).

Forced ascent of such magma causes extremely localized deformation at the interface with the surrounding wall rock where shear stresses are greatest (Hale and Wadge, 2008; Smith et al., 2011; Kennedy and Russell, 2012; Okumura et al., 2016). Strain localization is evidenced by the formation of an annular shear zone around the solidifying magma plug (Sparks et al., 2000; Watts et al., 2002; Cashman et al., 2008; Hale and Wadge, 2008; Holland et al., 2011;

Kendrick et al., 2012; Lavallée et al., 2013; Pallister et al., 2013; Hornby et al., 2015; Wallace et al., 2019a). Further deformation sequestered in the shear zone facilitates transit of the plug over hundreds to thousands of meters to the surface (Cashman et al., 2008; Okumura and Kozono, 2017).

These processes produce high aspect ratio lava domes and spines (Sparks et al., 2000; Cashman et al., 2008; Heap et al., 2016) such as observed at Soufrière Hills (Montserrat, 19952010; Voight et al., 1999; Watts et al., 2002; Loughlin et al., 2010; Ryan et al., 2010), Mount St. 
Helens (USA, 2004-2008; Iverson et al., 2006; Scott et al., 2008; Dzurisin et al., 2015); Mount Unzen (Japan, 1991-1995; Nakada et al., 1995a, 1999) and Santiaguito (Guatemala, 1922present; Rose, 1972; Holland et al., 2011; Rhodes et al., 2018). Many of these lava domes are enveloped in cataclastic carapaces of variably densified volcanic fault gouge representative of the conduit shear zone (Nakada et al., 1995a; Watts et al., 2002; Iverson et al., 2006; Cashman et al., 2008; Kennedy and Russell, 2012; Pallister et al., 2013; Rhodes et al., 2018). The fault gouge results from fracturing of the coherent magma/lava, followed by cataclasis of the particles (i.e., comminution, translation and rotation; Engelder, 1974) and simultaneous mechanical compaction. The physical properties and microstructures of the cataclastic materials record information about magma ascent and eruption processes including: i) the deformational processes governing magma ascent (e.g., Cashman et al., 2008; Kennedy et al., 2009; Kendrick et al., 2012; Pallister et al., 2013), ii) the extent and implications of in-conduit alteration (e.g., Wallace et al., 2019a), and iii) the efficiency of volcanic outgassing (e.g., Gaunt et al., 2014).

Here we describe the shear zone encasing a crystal-rich, glass-poor rhyodacitic lava dome (Dome C), part of Chaos Crags within the Lassen Volcanic Center (California, USA). The enveloping conduit-parallel shear zone is well-exposed by the partial collapse of the original lava dome, and the outcroppings reveal it to comprise unconsolidated gouge and variably competent cataclasites. Below we document the structural organization and textural properties of the Dome $\mathrm{C}$ cataclasites, as well as their microstructural, physical and mechanical properties. We use these observations and data on the Dome C shear zone materials to show that: (1) fracturing and cataclasis of the dacite at depth produced unconsolidated volcanic fault gouge, and (2) much of the gouge underwent solid-state sintering within the conduit to become the variably densified and lithified cataclasites observed at the surface. Solid-state sintering is a diffusion-driven 
process, akin to diffusion creep that causes crystalline particles to coalesce and results in densification (loss of porosity) and lithification (increase in competence/strength) (e.g., Rahaman, 2003). Here we show that solid-state sintering of the gouge must have occurred on the timescale of the dome-producing eruption. We conclude with microstructural evidence for refracturing of the sintered cataclasites at depth, indicating cycles of cataclasite reworking and resintering accompanied the extrusion process. These processes imply shear zone properties (i.e. permeability, porosity, strength) are highly transient and can modulate eruptive behavior during the eruption of crystal-rich, glass-poor lava domes.

\section{Geologic Setting}

\subsection{Chaos Crags}

Chaos Crags is within Lassen Volcanic National Park (California, USA) and is a part of the Lassen Volcanic Center, the southernmost volcanic center in the Cascades (Heiken and Eichelberger, 1980; Clynne, 1990). Chaos Crags is the youngest eruption in the Eagle Peak sequence, occurring $1103 \pm 13$ years B.P. ( $~ 850$ C.E.; Clynne et al., 2008a) and contributing to the formation of the silicic Lassen dome field (Clynne and Muffler, 2010, 2017; Muffler and Clynne, 2015). Chaos Crags consists of six rhyodacitic domes (from oldest to youngest: Domes A to F) and associated pyroclastic deposits (Christiansen et al., 2002; Clynne and Muffler, 2010, 2017; Muffler and Clynne, 2015) (Figure 1). Although the precise duration of the total eruption is unknown, paleomagnetic directions measured in pyroclastic units and in the dome lavas indicate it may have been less than a few decades (Clynne et al., 2008a).

Eruptive products from Chaos Crags are subdivided by their lithology. Dome $\mathrm{C}$ is the oldest of the Group 2 products, which generally have devitrified, microlite-rich groundmasses 
and whole rock $\mathrm{SiO}_{2}$ contents from 67 to 68.5 wt.\% (Clynne et al., 2008b; Clynne and Muffler, 2010; Quinn, 2014). The phenocryst assemblage includes plagioclase, biotite, hornblende and quartz, in order of decreasing abundance (Clynne and Muffler, 2010). Similar to other Group 2 products, Dome C lavas contain abundant (up to 20\%) mafic magmatic inclusions - basaltic andesite to andesite inclusions principally composed of amphibole, pyroxene and plagioclase microphenocrysts with subordinate amounts of olivine, clinopyroxene and plagioclase phenocrysts (Tepley et al., 1999; Underwood et al., 2012; Scruggs and Putirka, 2018).

\subsection{Dome C}

Approximately 350 years ago (mid 1600s C.E.; Heath, 1959; Clynne and Muffler, 2017), a majority of Dome $\mathrm{C}$ collapsed in three cold rock avalanches to form the $0.12-0.17 \mathrm{~km}^{3} \mathrm{Chaos}$ Jumbles deposit that extends NW of Dome C (Eppler et al., 1987; Clynne and Muffler, 2017) (Figure 1). The partial collapse bisected the dome (Figure 2a). The remnant of Dome C is semispherical in shape, with a near-vertical NW-facing exposure of the dome interior. The interior is pervasively oxidized and heavily jointed (Watts et al., 2013; Figure 2a). We sampled material that is representative of the dome's unaltered interior from the Chaos Jumbles deposit. A description of the dacite (hereafter unit " $\mathrm{D}$ ") is given in Table 1.

Along the SW and NE margins of Dome $\mathrm{C}$, the heavily jointed interior of the dome is overlain by a smooth upper surface. Where exposed on the SW margin (Figure 2b-d), this layer comprises three volcaniclastic units, which we sampled in situ (Figure 2c-d): (1) a pink, clastsupported breccia consisting of angular, interlocking clasts of dacite, and (2) a pink, highporosity cataclasite (hereafter " $\mathrm{C}_{\mathrm{Hi}}$ ") containing patches and discontinuous bands of (3) dark red, low-porosity cataclasite (hereafter " $\mathrm{C}_{\mathrm{Lo}}$ ") (detail in Figure $2 \mathrm{e}$ ). The unit $\mathrm{C}_{\mathrm{Lo}}$ shows a fracture 
pattern (Riedel shears) consistent with those observed in other volcanic shear zones (e.g., Mount

St. Helens; Cashman et al., 2008; Friedlander, 2012; Pallister et al., 2013) (Figure 2c-d).

Unconsolidated grey fault gouge (hereafter unit "G") is also exposed at the outermost edge of the SW margin (light grey region in Figure 2a). Where observed in situ, unit G is sandwiched between fractured grey dacite and an older, oxidized, dark grey hypersthene, augite and plagioclase-phyric andesite ("WR" in Figure 2a), which erupted in the middle Pleistocene (Christiansen et al., 2002; Clynne and Muffler, 2010).

These volcaniclastic units (Table 1) are parts of the shear zone that facilitated the ascent of Dome $\mathrm{C}$ lava to the surface. Figure $2 \mathrm{f}$ is a schematic showing the general structural organization of the shear zone.

\subsection{Sampling}

We collected samples from the units $\mathrm{D}, \mathrm{C}_{\mathrm{Hi}}, \mathrm{C}_{\mathrm{Lo}}$ and $\mathrm{G}$. Samples of the cataclasite units have specific sample IDs (L0 to L5; Table 1) and are shown in their respective collection locations within the shear zone in Figure 2f. For these samples, we assume the outermost planar surface of the outcrop was oriented vertically in the conduit during ascent (Figure 2b,d), and use this as a reference plane to orient samples for thin section preparation and coring. We estimate the thickness of the outcrop, from this outer surface to the start of the dacite breccia, to be $1.4 \mathrm{~m}$.

\section{Methods}

The whole rock major element chemical compositions of samples of units $\mathrm{D}, \mathrm{C}_{\mathrm{Hi}}, \mathrm{C}_{\mathrm{Lo}}$ and G were determined by XRF analysis at ALS Geochemistry laboratory in Vancouver (BC, Canada), based on $2 \mathrm{~g}$ aliquots of each sample (Table 2). Replicate analysis of aliquots of sample 
L2 from unit $\mathrm{C}_{\mathrm{Hi}}$ was used to establish analytical uncertainty. The mineral componentry of the same samples (Table 3) was determined by Rietveld refinement of X-ray diffraction spectra (Raudsepp et al., 1999).

Thin section billets oriented parallel (x-z plane in Figure 2) and perpendicular (y-z plane in Figure 2) to the kinematic plane were cut from samples of units $\mathrm{C}_{\mathrm{Hi}}$ and $\mathrm{C}_{\mathrm{Lo}}$. A billet was cut from an unoriented sample of unit D. These thin sections were analyzed using an optical microscope and a scanning electron microscope in back-scattered mode (BSE SEM) at the University of British Columbia (UBC), Canada.

We determined the powder (true) density $\left(\rho_{p} ; \mathrm{kg} / \mathrm{m}^{3}\right)$ of samples from units $\mathrm{D}, \mathrm{G}, \mathrm{C}_{\mathrm{Hi}}$ and $\mathrm{C}_{\mathrm{Lo}}$ using the following procedure: we crushed $10-15 \mathrm{~g}$ of material using a mortar and pestle to produce a fine powder. Each powder was then subdivided in to five aliquots. The mass of the first aliquot was measured using a high precision balance then transferred into a Micromeritics AccuPyc II 1340 helium pycnometer (at UBC) to determine the sample volume. The mass of a second aliquot was measured, added to the first aliquot in the helium pycnometer and then the powder's volume was remeasured. This additive process was repeated until all five aliquots were measured together in the pycnometer. Plotting the measured masses against the measured powder volumes, $\rho_{p}$ is the slope of the best-fit line that goes through the data and the origin (Table 4).

Thirty-seven right cylinders (12 or $20 \mathrm{~mm}$ in diameter, $15-40 \mathrm{~mm}$ in length) were cored from samples of units $\mathrm{D}, \mathrm{C}_{\mathrm{Hi}}$ and $\mathrm{C}_{\mathrm{Lo}}$. Of the four cores taken from each cataclasite sample (Table 4), half are oriented so their lengths are parallel to the extrusion direction (z-axis in Figure 2), and half perpendicular to the extrusion direction (x-axis in Figure 2). The thirteen cores prepared from blocks of dacite dome (unit D; Figure 2) collected from the Chaos Jumbles 
deposit were unoriented. Core ends were ground to parallel and then dried in a vacuum-oven at $40^{\circ} \mathrm{C}$ for at least 48 hours. Core diameters and lengths were measured using digital calipers, and core masses were measured using a high precision balance. The skeletal volume of each sample was measured using a Micromeritics AccuPyc II 1340 helium pycnometer (at the Institut de Physique du Globe de Strasbourg (IPGS), France). Using these measurements and $\rho_{p}$, sample bulk density $\left(\rho_{b} ; \mathrm{kg} / \mathrm{m}^{3}\right)$, total porosity $\left(\phi_{t} ;\right.$ fractional) and connected porosity $\left(\phi_{c}\right.$; fractional) were calculated (Tables 4,5).

The permeability $\left(k ; \mathrm{m}^{2}\right)$ of each core was measured using a benchtop gas (nitrogen) permeameter at the IPGS (see Heap and Kennedy (2016) for a schematic diagram) (Tables 4,5). Samples were placed within the permeameter and were pressurized around their circumference to a confining pressure of $1 \mathrm{MPa}$ and kept at these conditions for $1 \mathrm{~h}$ to ensure microstructural equilibration. Following equilibration, measurements of permeability were performed using the steady-state flow method: volumetric flow rates $(Q ; \mathrm{L} / \mathrm{min})$ were measured using a flowmeter for several pore pressure differentials $(\Delta P$; mbar) measured using a pore pressure transducer. We calculated permeability from these data while checking whether the data required auxiliary corrections (i.e., Klinkenberg and Forchheimer corrections). To do so, the raw permeability ( $k_{\text {raw }}$; $\mathrm{m}^{2}$ ) was first calculated for each pore pressure differential:

$$
k_{\text {raw }}=\frac{Q}{\left(\Delta P \cdot P_{m}\right)} \frac{\left(\mu L P_{d}\right)}{A} \quad \text { Eq. } 1
$$

where $\mu$ is the viscosity of the pore fluid (Pa s), $L$ is the sample length (m), $P_{d}$ is the downstream pore fluid pressure (mbar), $\Delta P$ is the difference between the upstream pore fluid pressure $\left(P_{u}\right)$ and $P_{d}, P_{m}$ is the mean pore fluid pressure $\left(P_{m}=\left(P_{u}-P_{d}\right) / 2\right)$ and $A$ is the sample cross-sectional area $\left(\mathrm{m}^{2}\right)$. If these data, when plotted as $1 / k_{\text {raw }}$ as a function of $Q$, can be well described by a positive linear slope, the Forchheimer correction is required (Table S1). Forchheimer corrections 
were necessary for most cores (Tables 4,5) and the true permeability was taken as the inverse of the y-intercept of the best-fit linear regression in the plot of $1 / k_{\text {raw }}$ as a function of $Q$. To check whether the Klinkenberg correction was also needed, the Forchheimer corrected permeability values for each pressure differential were plotted as a function of $1 / P_{m}$ The samples that required a Forchheimer correction did not also require a Klinkenberg correction. For the samples that did not require a Forchheimer correction, we checked whether a Klinkenberg correction was necessary. A Klinkenberg correction is required when the data on a plot of $k_{\text {raw }}$ as a function of $1 / P_{m}$ can be well described by a positive linear slope. This was not the case for our data and so when a Forchheimer correction was not needed, the permeability $\left(k_{D}, \mathrm{~m}^{2}\right)$ was calculated using the following relation:

$$
k_{D}=\frac{\partial Q}{\partial\left(\Delta P \cdot P_{m}\right)} \frac{\left(\mu L P_{d}\right)}{A} \quad \text { Eq. } 2 .
$$

Seven cataclasite cores, at least one from each of the identified layers, and eight cores of dacite were deformed uniaxially in compression until failure. See Heap et al. (2014b) for press schematic and details of method. All of the experiments were performed on oven-dry samples at a constant strain rate of $10^{-5} \mathrm{~s}^{-1}$. A lubricating wax was applied to the end-faces of the samples to avoid problems with friction between the sample and the pistons. During deformation, we recorded axial displacement and force using, respectively, a linear variable differential transducer (LVDT) and a load cell. Axial displacement was corrected for the deformation of the loading column. Axial displacement and force were converted to axial strain and stress using the sample dimensions. The uniaxial compressive strength (UCS; MPa) of the cores was taken as the peak axial stress the sample sustained before succumbing to macroscopic failure. We also determined the static Young's modulus ( $E$; GPa) for each of the samples from the pseudo-linear elastic portions of the stress-strain curves (see Heap et al., 2020). 
Four cores of dacite dome were deformed triaxially in compression. See Farquharson et al. (2017) for press schematic and details of method. These samples were vacuum-saturated in deionized water, inserted into a viton jacket and placed inside the pressure vessel. Confining $\left(P_{c}\right.$; $\mathrm{MPa})$ and pore fluid $\left(P_{p} ; \mathrm{MPa}\right)$ pressures were then increased using servo-controlled pumps. Once the samples reached their target pressure (between 15 and $30 \mathrm{MPa}$ and $10 \mathrm{MPa}$ for the confining and pore fluid pressures, respectively), they were left for a couple of hours to ensure microstructural equilibration. $P_{c}$ and $P_{p}$ were held constant during the experiment by the servocontrolled pumps. The samples were then deformed at a constant strain rate of $10^{-5} \mathrm{~s}^{-1}$. During deformation, axial displacement and force were measured by an LVDT and a load cell, respectively, which were converted to axial strain and stress using the sample dimensions. The axial displacement was corrected for the deformation of the loading column. We assume here a simple effective pressure law, where the effective pressure $\left(P_{\text {eff; }}\right.$, MPa) is the confining pressure minus the pore fluid pressure. The final dacite dome core, also vacuum-saturated in deionized water, was deformed uniaxially (using the same protocol described above) inside a water-filled cup.

\section{Results}

\subsection{Geochemistry and mineralogy}

The units $\mathrm{D}, \mathrm{G}, \mathrm{C}_{\mathrm{Hi}}$ and $\mathrm{C}_{\mathrm{Lo}}$ have common chemical compositions (Table 2) and modal mineralogy (Table 3). Mineralogically, the rocks comprise plagioclase (andesine, 40-45 wt.\%), high- (anorthoclase to sanidine) and low-temperature (microcline) alkali feldspars (20-25 wt.\%), $\mathrm{SiO}_{2}$ polymorphs (quartz, 12-15 wt.\%; cristobalite, 4-9 wt.\%), and minor (5-8 wt.\%) other phases (cf. Table 3). The XRD spectra also suggest the presence of a small quantity (4-8 wt.\%) 
of amorphous material which can be amorphous mineral phases, volcanic glass or highly comminuted mineral grains (Yund et al., 1990). There is no systematic variation in the proportion of minerals (including cristobalite) or amorphous material between units (Table 3). Based on the identical geochemistry and mineralogy of the units, all shear zone materials appear to originate from the Dome $\mathrm{C}$ dacite. There is no evidence for precipitation of additional phases or melting of the gouge or dacite.

\subsection{Microstructure}

Low magnification photomicrographs show the representative colors and textures of the groundmass of the unit D (Figure 3a) and the matrices of units $\mathrm{C}_{\mathrm{Hi}}$ (Figure $3 \mathrm{~d}$ ) and $\mathrm{C}_{\mathrm{Lo}}$ (Figure 3g). At high magnification, BSE SEM images of the dacite (Figure 3b,c) and cataclasites (Figure $3 \mathrm{~d}, \mathrm{e}, \mathrm{h}, \mathrm{i})$ are different. The groundmass of the dacite is cross-crossed by acicular microlites (Figure 3c) and features roughly circular, fractured patches of cristobalite (see Figure 3b). Irregularly shaped pores are present throughout the groundmass but show no specific relationship to mineral phases. In unit $\mathrm{C}_{\mathrm{Hi}}$, the matrix comprises many blocky or subrounded clasts often connected to one another by thin necks of crystalline material (arrows in Figure 3f); both acicular mineral grains and patches of cristobalite are absent (Figure 3e). The necks, which extend between particles of various shape, size and composition, are oriented at high angles to the surfaces of the substrate grains, rather than at low contact angles commonly associated with wetting of particles. Interconnected irregular or subrounded void spaces sit between necks, at the junction points of the coalescing clasts. Particle coalescence is often concentrated at the edge of larger grains (Figure $3 \mathrm{e}$ ). In unit $\mathrm{C}_{\mathrm{Lo}}$, nearly all particles have coalesced (Figure $\left.3 \mathrm{~h}, \mathrm{i}\right)$. The 
number and size of void spaces has decreased relative to $\mathrm{C}_{\mathrm{Hi}}$, and many of the remaining pore spaces are isolated from one another. Lastly, no glass was identified in samples of cataclasite.

There are other notable textural features found only within the cataclasite units (Figure 4). For example, there are shattered plagioclase grains that have been sheared to form highporosity monomineralic lenses in $\mathrm{C}_{\mathrm{Lo}}($ Figure $4 \mathrm{a}, \mathrm{b})$ and $\mathrm{C}_{\mathrm{Hi}}$ (Figure $4 \mathrm{c}$ ). The plagioclase particles in the lenses are angular and have jig-saw-fit textures. In addition, mafic inclusions in $\mathrm{C}_{\mathrm{Hi}}$ and $\mathrm{C}_{\mathrm{Lo}}$ are oxidized and have been sheared to form overall elongated curvilinear shapes (Figure $4 c, d)$. In contrast, mafic inclusions in unit D are frequently fresh, typically near-equant in their dimensions, and show no textures consistent with having been viscously stretched. Finally, there are rounded clasts of $\mathrm{C}_{\mathrm{Lo}}$ within $\mathrm{C}_{\mathrm{Hi}}$ (Figure $\left.4 \mathrm{e}, \mathrm{f}\right)$. We discuss these clasts further in Section 5.4.

\subsection{Physical and mechanical properties}

Table 4 summarizes the results of physical property measurements of cores taken from samples of units $\mathrm{D}, \mathrm{C}_{\mathrm{Hi}}$ and $\mathrm{C}_{\mathrm{Lo}}$. Across the dataset, $\phi_{t}$ and $\phi_{c}$ are within uncertainty $( \pm 0.01)$ of one another, indicating there is little to no isolated porosity. $\phi_{t}$ and $\phi_{c}$ vary from 0.07 to 0.23

(Table 4). Permeability is positively correlated with porosity, and varies from $1.18 \times 10^{-15}$ to 4.04 $\times 10^{-14} \mathrm{~m}^{2}$. By unit, cores of $\mathrm{C}_{\mathrm{Lo}}$ have the lowest porosities and permeabilities, while cores of $\mathrm{C}_{\mathrm{Hi}}$ have the highest (Table 4). $\mathrm{C}_{\mathrm{Hi}}$ shows the most variability in physical property values (Table 4). Cataclasite units show weak porosity and permeability anisotropy as both values are often higher in cores oriented parallel to the extrusion direction. Cores of $\mathrm{D}$ have intermediate porosities and permeabilities (Table 4).

The measured uniaxial compressive strengths and Young's moduli of the units are also correlated to their porosities: $\mathrm{C}_{\mathrm{Lo}}$ is strong and stiff (UCS: 86.0 MPa; E: 16.0 GPa), while cores 
of $\mathrm{C}_{\mathrm{Hi}}$ are considerably weaker and have lower Young's moduli, with UCS varying from 20.4 to 42.0 MPa and $E$ varying from 5.0 to $9.2 \mathrm{GPa}$ (Table 4). Cores of D have an intermediate strength and Young's modulus (UCS: 46.3 to $53.2 \mathrm{MPa}$; E: 9.0 to 10.2 GPa; Table 4).

The failure mode of the dacite cores deformed triaxially was brittle over the tested pressure range (i.e., up to an effective pressure of $20 \mathrm{MPa}$ ) (Figure S1). These experiments show that the compressive strength $\left(P_{d i f f} ; \mathrm{MPa}\right)$ of unit D increased from 50.2 to $228.6 \mathrm{MPa}$ as the effective pressure was increased from 0 to $20 \mathrm{MPa}$ (Table 5).

Measured values of permeability and connected porosity for samples of cataclasite are plotted in Figure 5 and compared to a model curve for the permeability and porosity of granular material undergoing isotropic densification (Wadsworth et al. 2016). The close fit between the model and the measured values of $\phi_{c}$ and $k$ for the cataclasites suggests that the shear zone materials have been mainly subject to isotropic densification and that shear stresses did not play a major role (Figure 5). The measured physical properties of the coherent dacite are added for comparison.

Direct measurement of porosity and permeability for the unconsolidated gouge was not possible. We infer its porosity to be 0.40 , equal to that of a packed powder (Rahaman, 2003). The Wadsworth et al. (2016) model would predict a permeability of $2.4 \times 10^{-13} \mathrm{~m}^{2}$ based on that porosity value (Figure 5). The gouge is expected to have little to no cohesive strength (e.g., Moore et al., 2008; Samuelson et al., 2008; Lavallée et al., 2014). Including these approximations, physical properties across the shear zone vary substantially, including for connected porosity $(\Delta \sim 0.33)$, permeability $\left(\Delta \sim 10^{2}\right)$, strength $(\Delta>80 \mathrm{MPa})$ and Young's modulus $(\Delta>16 \mathrm{GPa})$. 
Figure 6 shows the spatial distribution of physical and mechanical properties. The majority of the shear zone is made up of weak, high porosity and high permeability $\mathrm{C}_{\mathrm{Hi}}$. However, the shear zone close to the dacite dome contains thin, discontinuous bands (Figures $2 \mathrm{~d}, \mathrm{e})$ and diffuse patches (Figure $4 \mathrm{c}$ ) of strong, stiff, low-porosity and low-permeability $\mathrm{C}_{\mathrm{Lo}}$. As a result, the porosity and permeability of the shear zone decrease and the strength and Young's modulus increase as the margin between the dome and the cataclastic rocks is approached (Figure 6). Notably, the porosity and permeability and the strength and Young's modulus of $\mathrm{C}_{\mathrm{Lo}}$ are, respectively, lower and higher than the dacite dome.

\section{Discussion}

The variably densified and lithified cataclasite units that make up the Dome $\mathrm{C}$ shear zone evidence a deep-seated gouge production event followed by the densification and lithification of the gouge within the conduit on the timescale of the eruption. The lithification process was so effective that it created cataclasites that are stronger and less permeable than the dome interior (Figure 6). Identifying the relevant lithification mechanism, and the associated magnitudes and timescales of densification and lithification, inform on Dome $\mathrm{C}$ ascent conditions.

\subsection{Densification and lithification by solid-state sintering}

Densification and lithification of granular volcanic materials can occur by a number of mechanisms, including viscous sintering or annealing and compaction (welding) (e.g., Quane et al., 2009; Vasseur et al., 2013; Heap et al., 2014a; Wright and Cashman, 2014; Kolzenburg et al., 2019), and pore occlusion by mineral precipitation (e.g., Wright et al., 2011; Horwell et al., 2013; Heap et al., 2019). However, the lack of groundmass glass in thin section, the paucity of 
amorphous material, the absence of low-temperature precipitated phases, and the consistency in modal mineralogy across the shear zone and dacite lava preclude densification and lithification by viscous processes, cementation, or melting. In addition, there is no mineralogical or textural evidence to support the presence of a permeating liquid and densification by the dissolution and re-precipitation of minerals (i.e., Ostwald ripening, pressure solution).

Simultaneous mechanical compaction and shear-driven particle rearrangement can contribute to the densification of an unconsolidated granular material (e.g., Marone et al., 1990; Faulkner et al., 2018). However, the extent of mechanical densification is limited to the porosity of densely packed powders (i.e., $~ 0.40$; Rahaman, 2003). In addition, the timescales of these mechanical densification processes may be very short, especially when compared to the timescales required for other densification mechanisms. In the volcanic setting considered here, maximum mechanical densification, forming a gouge having $\phi_{t} \sim 0.40$, likely occurs almost instantaneously following the magma/lava fracturing event.

In the Dome C cataclasites, lithification and densification to $\phi_{t} \ll 0.40$ involves crystalline particles of varying sizes becoming conjoined by thin necks of new crystalline material. This particle coalescence evidences solid-state sintering, a diffusion-driven process akin to diffusion creep that converts unconsolidated crystalline granular materials into porous composites (Ashby, 1974; Arzt et al., 1983; Zhu et al., 1999; Rahaman, 2003; Ryan et al., 2018b). Solid-state sintering operates at temperatures as low as half of the crystalline material's melting temperature and does not require the presence of fluid nor melt (e.g., Ashby, 1974; Rahaman, 2003). The rates of sintering are accelerated by increases in effective pressure and temperature and by reductions in particle size. The extent of solid-state sintering depends on temperature and pressure, as well as, the time spent at those conditions (e.g., Rahaman, 2003). 
Long dwell times result in more extensive sintering, producing denser, more competent (stronger), less porous and less permeable materials (Ryan et al., unpublished results).

Ryan et al. (unpublished results) conducted hot-pressing experiments to determine solidstate sintering efficiency as a function of the experimental confining pressure $(P, \mathrm{MPa})$, temperature $(T, \mathrm{~K})$ and time $(t, \mathrm{~s})$. These high-temperature $\left(700-900^{\circ} \mathrm{C}\right)$, high-pressure $(20-70$ MPa) experiments on unconsolidated dacitic fault gouge from the 2004-2008 eruption of Mount St. Helens produced dense, competent rocks by solid-state sintering over a period of hours to days. They used the data to create a $t-P-T$-dependent model for densification by solid-state sintering:

$$
\rho_{r}=\rho_{o}+a \exp \left(\frac{b}{T}\right) P^{c} \ln (t) \quad \text { Eq. } 3 .
$$

where $\rho_{r}$ is the relative density $\left(\rho_{r}=1-\phi_{t}=\rho_{b} / \rho_{p}\right.$, where $\rho_{b}$ is bulk density and $\rho_{p}$ is powder density)), $\rho_{o}$ is the initial relative density, and the coefficients $a(0.045 \pm 0.018), b(-3049 \pm 231)$, and $c(0.442 \pm 0.006)$ are the adjustable model parameters fit using an unweighted least squares approach (Ryan et al., unpublished results). Equation 3 can also be rearranged to solve for the sintering time necessary to achieve a specified porosity:

$$
t=\exp \left(\frac{\rho_{r}-\rho_{o}}{a \exp \left(\frac{b}{T}\right) P^{c}}\right) \quad \text { Eq. } 4 .
$$

In volcanic conduits we expect mechanical densification to occur immediately, implying that the rate-limiting densification process is solid-state sintering. To model the extent of sintering and minimum sintering times for the cataclasites enveloping the Chaos Crags Dome C, we assume the following:

- The initial gouge formed by syn-ascent faulting at a depth of $\sim 1 \mathrm{~km}$. This is informed by the observation and interpretation of repetitive seismic events at depths $<1.5 \mathrm{~km}$ at other 
dome-building volcanoes (Goto, 1999; Nakada et al., 1999; Melnik and Sparks, 2002;

Iverson et al., 2006; Neuberg et al., 2006; Moran et al., 2008; Thelen et al., 2008; Lamb et al., 2015).

- $\quad$ The minimum pressure acting on the conduit wall rock-gouge layer $\left(P_{\min } ; \mathrm{MPa}\right)$ was the depth-dependent lithostatic pressure $\left(P_{\min }=\rho g h\right.$, where $\rho$ is a representative bulk density (2300 kg/m ${ }^{3}$; Table 4), $g$ is gravitational acceleration $\left(9.81 \mathrm{~m} / \mathrm{s}^{2}\right)$ and $h$ is the depth (up to $1000 \mathrm{~m})$ ) (Figure 7a).

- $\quad$ The maximum compressive pressure $\left(P_{\max }\right.$; MPa) acting on the gouge was dictated by the compressive fracture strength of the dacite as a function of depth $(h)$. We use the uniaxial and triaxial strength data (Table 5) to constrain the relationship between $P_{\max }$ and $h$ - by

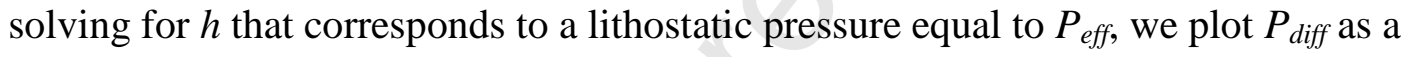
function of depth and fit the triaxial and uniaxial data (Tables 4,5). The resulting linear best-fit line is shown in Figure 7a. See Supplement S2 for additional details.

- $\quad$ Phase equilibria experiments suggest pre-eruptive storage conditions for Chaos Crags lavas were $770 \pm 10^{\circ} \mathrm{C}$ at $145 \pm 25 \mathrm{MPa}(\sim 4.5-6.5 \mathrm{~km})$ (Quinn, 2014). Allowing for slight cooling during ascent to the surface, we assume the gouge temperature was $\sim 725^{\circ} \mathrm{C}$. This value is in agreement with thermal measurements of surficial exposures of other domes, their fumaroles and associated pyroclastic flows $\left(650-800^{\circ} \mathrm{C}\right.$; Goto, 1999; Voight et al., 1999; Sparks et al., 2000; Schneider et al. 2008; Scott et al., 2008; Vallance et al., 2008).

Figure $7 \mathrm{~b}$ shows the decrease in porosity as a result of solid-state sintering, as a function of depth, pressure acting on the gouge $\left(P_{\min }\right.$ vs. $\left.P_{\max }\right)$ and time. Three shaded fields show the porosities of units $\mathrm{G}$ (the starting condition; $\phi_{t}=0.40$ ), $\mathrm{C}_{\mathrm{Lo}}$ and $\mathrm{C}_{\mathrm{Hi}}$. Porosity loss with time is greatest at the depth of gouge generation $(1 \mathrm{~km})$ - after 10 days modelled porosities are $\sim 0.07$ to 
0.28 , depending on $P$. At $500 \mathrm{~m}$ depth, sintering is less efficient, so after 10 days modelled porosities are $\sim 0.13$ to 0.30 . At any depth, with increasing time, porosity continues to decrease but at a slower rate.

We model the minimum sintering time required to form cataclasites having porosity values observed in $\mathrm{C}_{\mathrm{Hi}}\left(\phi_{t} \sim 0.20\right)$ and $\mathrm{C}_{\mathrm{Lo}}\left(\phi_{t} \sim 0.08\right)$. Where $P=P_{\max }$, the minimum sintering times needed to produce $\mathrm{C}_{\mathrm{Hi}}$ and $\mathrm{C}_{\mathrm{Lo}}$ at $1 \mathrm{~km}$ depth are 1 hour and 6 days, respectively (Figure 7c). With decreasing depth, minimum sintering times increase as follows: i) at $750 \mathrm{~m}$ depth sintering times are 2.5 hours and 24 days, ii) at $500 \mathrm{~m}$ depth sintering times are 8 hours and 170 days.

\subsection{Ascent rate and eruption duration}

There are no direct or indirect determinations of ascent $(\mathrm{m} / \mathrm{s})$ or extrusion $\left(\mathrm{m}^{3} / \mathrm{s}\right)$ rates for the magma plug that produced Dome $\mathrm{C}$, nor estimates of the eruption duration. Watts et al. (2013) suggested, based on morphology and the character of the shear zones, that Dome C was comparable to the "shear lobes" at Soufrière Hills suggesting extrusion rates of $<7 \mathrm{~m}^{3} / \mathrm{s}$ (Watts et al., 2002). Quinn (2014) used continuous decompression experiments to determine the decompression rates needed to produce Chaos Crags Group 1-type and Group 2-type magmas. Based on phenocryst textures (e.g., presence or absence of dehydration reaction rims on biotite and amphibole) and systematic changes in glass composition (e.g., increasing $\mathrm{SiO}_{2}$ and $\mathrm{K}_{2} \mathrm{O}$ and decreasing $\mathrm{Al}_{2} \mathrm{O}_{3}$ and $\mathrm{CaO}$ with decreasing decompression rate, corresponding to trends in the change in the composition of Chaos Crags glasses with time), Quinn (2014) showed Group 1type lavas can be produced where decompression rates are $>2.6 \mathrm{MPa} / \mathrm{hr}(>100 \mathrm{~m} / \mathrm{hr}$ ascent 
velocities), while Group 2-type lavas (i.e., Dome $\mathrm{C}$ dacite) require decompression rates $<2.6$ $\mathrm{MPa} / \mathrm{hr}(<100 \mathrm{~m} / \mathrm{hr}$ ascent velocities $)$.

Ryan et al. (2018a) suggested the physical properties of shear zone materials that had undergone solid-state sintering could be used as a geospeedometer and could inform on cataclasite (and, by proxy, lava) ascent rate. Here we test this conceptual model for the first time: the shaded fields in Figure 7c define the critical depth-time conditions ("sintering windows") for $\mathrm{C}_{\mathrm{Hi}}$ or $\mathrm{C}_{\mathrm{Lo}}$. At Chaos Crags the occurrence of $\mathrm{C}_{\mathrm{Lo}}$ dictates the minimum required sintering time. That window therefore constrains the range of possible gouge ascent rates. Even when accounting for $P_{\max }$ decreasing during gouge ascent (see Supplement S3 for details), only at ascent rates $\leq 10 \mathrm{~m} / \mathrm{d}$ does the ascending magma intersect the sintering window needed to produce $\mathrm{C}_{\mathrm{Lo}}$ (Figure 7c; Figure S3). Assuming ascent of the magma plug is coupled to that of these sintered cataclasites, $10 \mathrm{~m} / \mathrm{d}$ represents a maximum ascent rate for the Dome $\mathrm{C}$ lavas. The width of the Dome C remnant (Figure 1,2) limits the maximum diameter of the vent to $\sim 250 \mathrm{~m}$; a linear ascent rate of $10 \mathrm{~m} / \mathrm{d}$ would yield a maximum volumetric extrusion rate of $5.7 \mathrm{~m} / \mathrm{s}$.

Our modelled ascent and extrusion rates agree well with observations from other intermediate dome-building volcanic systems. During the 2004-2008 eruption of Mount St. Helens (conduit diameter: 150-200 m), spine extrusion was initially fast $(15-25 \mathrm{~m} / \mathrm{d})$ but slowed with time, featuring linear effusion rates $\leq 10 \mathrm{~m} / \mathrm{d}$ during the eruption of spines 3-7 (Vallance et al., 2008; Schneider et al., 2012). Corresponding measured extrusion rates were $\leq 6 \mathrm{~m}^{3} / \mathrm{s}$ (Vallance et al., 2008; Schneider et al., 2012). During the 1991-1995 eruption of Mount Unzen, subsurface magma ascent rates were estimated to be 13-40 m/d (Nakada et al., 1995b). Extrusion rates measured at the surface were $~ 3-6 \times 10^{5} \mathrm{~m}^{3} / \mathrm{d}\left(3.5-7.0 \mathrm{~m}^{3} / \mathrm{s}\right)$ in the first pulse of exogenous growth and $\sim 1-3 \times 10^{5} \mathrm{~m}^{3} / \mathrm{d}\left(1.2-3.5 \mathrm{~m}^{3} / \mathrm{s}\right)$ in the second pulse (Nakada et al., 1999). 
With estimates of the depth of gouge generation $(1 \mathrm{~km})$, the pre-eruptive surface (break in the slope of Chaos Crags deposits at 2100 masl) and the original maximum height of the dome (peak of the Dome C remnant at $\sim 2495$ masl), we use our modelled maximum linear ascent rate to constrain the duration of the Dome $\mathrm{C}$ eruption: Dome $\mathrm{C}$ magmas spent a minimum of 100 days in transit from $1 \mathrm{~km}$ depth, and erupted at the surface for a minimum of 39.5 days, producing a dome $395 \mathrm{~m}$ high.

\subsection{Outgassing behavior during solid-state sintering}

Permeability loss accompanies densification and lithification by solid-state sintering (Ryan et al., 2018b, unpublished results; Zhu et al., 1999). At Dome C, solid-state sintering has caused $\mathrm{C}_{\mathrm{Hi}}$ and $\mathrm{C}_{\mathrm{Lo}}$ to be 1 and $>2$ orders of magnitude less permeable than the unconsolidated gouge (Figure 5). Permeability losses of these magnitudes can occur over a period of hours to days depending on the densification depth (Figure 7b). Rapid loss of connected void spaces in volcanic systems will inevitably inhibit the egress of volcanic gases, leading to their accumulation in the subsurface. In the case of the Dome $\mathrm{C}$ shear zone, building fluid pressures likely promoted vertical gas transmission through the cataclasite units. Given the weak permeability anisotropy observed in units sampled at the surface, some horizontal transmission may also have occurred, allowing gases to reach less-densified cataclasites or even unconsolidated gouge. Irrespective of the orientation of gas transmission, the extent of outgassing was ultimately moderated by the competition between sintering-driven permeability loss and rising gas overpressures. In Section 6 we discuss further the competition between these effects for dome-building systems generally. 


\subsection{Cyclical deformation and sintering in the shear zone}

Microstructural features in $\mathrm{C}_{\mathrm{Hi}}$ and $\mathrm{C}_{\mathrm{Lo}}$ (e.g., sheared plagioclase lenses and mafic inclusions in Figure 4) support a complex deformation history for these densified units. There is microstructural evidence for at least two cycles of cataclasis and sintering within the shear zone during ascent, expressed by rounded clasts of $\mathrm{C}_{\mathrm{Lo}}$ within the $\mathrm{C}_{\mathrm{Hi}}$ unit (Figure $\left.4 \mathrm{e}, \mathrm{f}\right)$. This suggests the following series of events occurred: (1) gouge formed by fracturing and cataclasis; (2) initial sintering produced $\mathrm{C}_{\mathrm{Lo}}$; (3) $\mathrm{C}_{\mathrm{Lo}}$ fractured at depth and fragments were comminuted to produce a cataclasite-derived gouge; (4) shear concentrated in the gouge layer caused rounding of what were presumably angular clasts of pre-existing sintered gouge; (5) the cataclasite-derived gouge re-sintered to produce $\mathrm{C}_{\mathrm{Hi}}$.

The time required for re-sintering depends on the depth at which cataclasis occurs. For example, the fracturing and cataclasis event that formed the clasts in Figures 4e,f likely occurred deeper in the conduit, allowing for sintering times of a few hours to days (Figure $7 \mathrm{~b}, \mathrm{c}$ ). These short sintering times allow for the re-densification and re-lithification of the gouge to form $\mathrm{C}_{\mathrm{Hi}}$. In contrast, we suggest that the gouge unit observed at the surface (Figure 2) likely formed in a similar secondary gouge-generation event, albeit closer to the surface where sintering times are significantly longer, approaching hundreds of days (Figure $7 \mathrm{~b}, \mathrm{c}$ ). With these long sintering times, there was no opportunity for unit $\mathrm{G}$ to re-densify and re-lithify, so it extruded at the surface as unconsolidated granular material.

Overall, the features in Figure 4 demonstrate that deformation attending ascent and extrusion of Dome C lavas was partitioned, at least partially, into competent cataclasites. Despite solid-state sintering transforming them into strong, low-porosity materials (Figure 6), the competent cataclasites continued to play an active role in facilitating ascent of the dacite magma 
plug. This is in conflict with expectation that deformation would be sequestered within the weakest shear zone unit (i.e., gouge). In light of these observations, we consider below the consequences of shear zone densification and lithification for ascent and eruptive processes for Dome $\mathrm{C}$ and lava domes generally.

\section{Implications beyond Chaos Crags}

The exposed shear zone at Dome $\mathrm{C}$ of Chaos Crags preserves evidence of solid-state sintering occurring within the hot volcanic conduit, leading to the densification and lithification of the gouge over hours to hundreds of days (Figures $7 \mathrm{~b}, \mathrm{c}$ ). Microstructures in the cataclasites also show that despite associated porosity loss and material strengthening, deformation continued to occur within the sintering portions of the shear zone.

In general, the properties of intra-conduit shear zones govern magma plug ascent processes. For example, in shear zones composed of unconsolidated gouge, the frictional behavior of the gouge dictates the force resisting the magma's advance to the surface (Iverson et al., 2006; Cashman et al., 2008; Moore et al., 2008; Samuelson et al., 2008; Costa et al., 2012; Kennedy and Russell, 2012; de' Michieli Vitturi et al., 2013; Lavallée et al., 2014; Okumura et al., 2015). In shear zones containing silicate melt, the distribution and rheological response of the melt may facilitate ascent (e.g., Di Toro et al., 2006; Wallace et al., 2019b), or cause the plug to stall in the subsurface (e.g., Kendrick et al., 2014; Hornby et al., 2015; Okumura et al., 2015). Similarly, the evolving connectivity of void spaces in gouge-filled or melt-bearing shear zones can suppress or enhance volatile outgassing (Rust et al., 2004; Tuffen and Dingwell, 2005;

Edmonds and Herd, 2007; Holland et al., 2011; Lavallée et al., 2013; Gaunt et al., 2014; Okumura and Sasaki, 2014; Heap et al., 2015; Colombier et al., 2017; Kolzenburg et al., 2019). 
Based on our analysis and modelling, we suggest the rapid densification and lithification of crystal-rich volcanic shear zones by solid-state sintering will change the efficiency of magma ascent and volatile outgassing. This is shown schematically in Figure 8: upon shear zone formation, it comprises unconsolidated high-porosity, high-permeability gouge with low cohesion (Figure 8a,b). Volcanic gases are easily transmitted through the gouge to the surface, and magma plug ascends as a result of frictional sliding (Figure 8b). With time, the gouge sinters in response to stresses acting on particles and high temperatures within the conduit. Sintering converts the gouge to a cataclasite. Over short times, the cataclasite is still more permeable and less strong than the magma plug itself (Figure 8c). However, as the shear zone continues to sinter, cataclasites are less permeable and considerably stronger than the magma (Figure 8d).

There are two major consequences of these changes in the physical and mechanical properties of the shear zone: the movement of the plug is resisted by an increasingly strong, lithifying margin but is also driven by rising gas pressures as solid-state sintering suppresses outgassing. The competition between these effects will dictate whether the plug stalls in the subsurface (Figure 8d) or the sintered cataclasite undergoes hydrofracturing in response to elevated pore pressures (Figure 8e). In the latter case, fracturing could release sufficient stored energy to generate a small, impulsive earthquake (e.g., Iverson et al., 2006; Lamb et al., 2015), and could cause the sudden, explosive release of trapped pressurized gases at the surface. In the subsurface, subsequent cataclasis would result in the incorporation (cannibalization) of sintered gouge fragments, producing fault gouge (Figure 8f) and initiating another cycle of sintering (Figure 8a).

At other volcanoes, unexpected changes in the rate, intensity or style of eruptive behavior, including transitions from effusive to explosive activity, are common during dome- 
building eruptions (e.g., Norton et al., 2002; Rowe et al., 2008; Holland et al., 2011). In crystalrich systems, these shifts may reflect the evolving physical and mechanical properties of the shear zone as it undergoes solid-state sintering. As an example, there were several large outgassing events in 2005 at Mount St. Helens, in the middle of the 2004-2008 spine-producing eruption (Rowe et al., 2008). These energetic outgassing events have been interpreted as explosive releases of accumulated gas pressure; the material ejected was primarily fault gouge (Cashman et al., 2008; Rowe et al., 2008). BSE images of the ash (Figure 12c,f in Rowe et al. 2008) shows several of the subrounded ash particles to have similar textures as in the Chaos Crags cataclasites. We propose the formation and ejection of these particles may have resulted from the same sequence shown in Figure 8: (1) solid-state sintering of gouge creates lowpermeability densified cataclasite that limit the egress of magmatic fluids, (2) in response to gas overpressures, the cataclasite in the shear zone undergoes near-simultaneous fracturing and cataclasis, and (3) rounded clasts of densified cataclasites are ejected during the explosive release of pressurized gases. Comparison of modelled sintering times and the recurrence interval of explosive activity in crystal-rich volcanic systems may reveal the catalyst for transitions in eruptive behavior.

\section{Conclusion}

The shear zone of Dome $\mathrm{C}$ at Chaos Crags comprises cataclastic units that preserve textural evidence of (1) gouge generation at depth, (2) syn-eruption densification and lithification of the shear zone by solid-state sintering, (3) deformation of competent, sintered cataclasites, despite their considerable strength, and (4) cyclical cataclasis and re-sintering of the shear zone within the conduit during the eruption (a period of hundreds of days). In previous models for the 
ascent of crystal-rich, glass-poor magma plugs and the eruption of lava domes, the potential for the lithification of the shear zones was not considered. We suggest rapid strengthening and permeability loss within the sintering shear zone will influence ascent and eruption dynamics, perhaps initiating or perpetuating the cycles of effusive-to-explosive behavior observed at many dome-producing volcanoes.

\section{Acknowledgements}

The work was permitted by the United States National Park Service (study number: LAVO00050; permit number: LAVO-2019-SCI-0010), and was supported by the Natural Sciences and Engineering Research Council of Canada (NSERC) Discovery Grants program (RGPIN-201803841; JKR). We thank Stephan Kolzenburg and Martin Harris for their help in the field, Fabian Wadsworth for providing us with the code for the permeability model from Wadsworth et al. (2016), and Elisabetta Pani for her help with Rietveld refinement of X-ray diffraction spectra. Thierry Reuschlé is thanked for maintaining the uniaxial and triaxial deformation apparatus at IPG Strasbourg. We thank two anonymous reviewers and John Pallister for their constructive comments. Any use of trade, firm, or product names is for descriptive purposes only and does not imply endorsement by the U.S. Government.

\section{CRediT author statement}

Amy Ryan: Conceptualization, Investigation, Formal Analysis, Writing-Original Draft, WritingReview and Editing, Visualization. Michael Heap: Conceptualization, Investigation, WritingReview and Editing. Kelly Russell: Conceptualization, Writing-Review and Editing, 
Supervison. Lori Kennedy: Resources, Writing-Review and Editing. Michael Clynne:

Resources, Writing-Review and Editing.

\section{Declaration of competing interest}

The authors declare that they have no known competing financial interests or personal relationships that could have appeared to influence the work reported in this paper.

\section{Data availability}

Data will be made available upon request.

\section{References}

Arzt, E., Ashby, M.F., and Easterling, K.E. (1983) Practical applications of hot-isostatic pressing diagrams: four case studies. Metallurgical Transactions A, 14A, 211-221.

Ashby, M.F. (1974) A first report on sintering diagrams. Acta Metallurgica, 22, 275-289.

Cashman K.V., Thornber, C.R., and Pallister, J.S. (2008) From dome to dust: shallow crystallization and fragmentation of conduit magma during the 2004-2006 dome extrusion of Mount St. Helens, Washington. In D.R. Sherrod, W.E. Scott, and P.H. Stauffer, Eds., A Volcano Rekindled: The Renewed Eruption of Mount St. Helens, 2004-2006. U.S. Geological Survey Professional Paper 1750, p. 387-413.

Christiansen, R.L., Clynne, M.A., and Muffler, L.J.P. (2002) Geologic map of the Lassen Peak, Chaos Crags, and Upper Hat Creek area, California. U.S. Geological Survey Geological Investigations Series I-2723, 1 sheet, scale 1:24,000, pamphlet 17 p.

Clynne, M.A., and Muffler, L.J.P. (2010) Geologic map of Lassen Volcanic National Park and vicinity. U.S. Geological Survey Scientific Investigations Map 2899, 3 sheets, scale 1:50,000, pamphlet $116 \mathrm{p}$.

Clynne, M.A., and Muffler, L.J.P. (2017) Geological field-trip guide to the Lassen segment of the Cascades Arc, Northern California. U.S. Geological Survey Scientific Investigations Report 2017-5022-K2, 65 p. 
Clynne, M.A., Christiansen, R.L., Trimble, D.A., and McGeehin, J.P. (2008a) Radiocarbon dates from volcanic deposits of the Chaos Crags and Cinder Cone eruptive sequences and other deposits, Lassen Volcanic National Park and vicinity, California. U.S. Geological Survey Open-file Report 02-290, 18 p.

Clynne, M.A., Muffler, L.J.P., Siems, D.F., Taggart, J.E., and Bruggman, P. (2008b) Major and EDXRF trace element chemical analyses of volcanic rocks from Lassen Volcanic National Park and vicinity, California. U.S. Geological Survey Open-file Report 2008-1091, 10 p.

Clynne, M.A. (1990) Stratigraphic, lithologic, and major element geochemical constraints on magmatic evolution at Lassen Volcanic Center, California. Journal of Geophysical Research, 95, 19651-19669.

Colombier, M., Wadsworth, F.B., Gurioli, L., Scheu, B., Kueppers, U., Di Muro, A., and Dingwell, D.B. (2017) The evolution of pore connectivity in volcanic rocks. Earth and Planetary Science Letters, 462, 99-109.

Costa, A., and Wadge, G., and Melnik, O. (2012) Cyclic extrusion of a lava dome based on a stick-slip mechanism. Earth and Planetary Science Letters, 337-338, 39-46.

de' Michieli Vitturi, M., Clarke, A.B., Neri, A., and Voight, B. (2012) Extrusion cycles during dome-building eruptions. Earth and Planetary Science Letters, 371-372, 37-48.

Di Toro, G., Hirose, T., Nielsen, S., Pennacchioni, G., and Shimamoto, T. (2006) Natural and experimental evidence of melt lubrication of faults during earthquakes. Science, 311, 647649.

Dzurisin, D., Moran, S.C., Lisowski, M., Schilling, S.P., Anderson, K.R., and Werner, C. (2015) The 2004-2008 dome-building eruption at Mount St. Helens, Washington: epilogue. Bulletin of Volcanology, 77, 89.

Edmonds, M., and Herd, R.A. (2007) A volcanic degassing event at the explosive-effusive transition. Geophysical Research Letters, 34, L21310.

Engelder, J.T. (1974) Cataclasis and the Generation of Fault Gouge. GSA Bulletin, 85, 15151522.

Eppler, D.B., Fink, J., and Fletcher, R. (1987) Rheologic properties and kinematics of emplacement of the Chaos Jumbles rockfall avalanche, Lassen Volcanic National Park, California. Journal of Geophysical Research, 92, 3623-3633. 
Farquharson, J. I., Baud, P., and Heap, M. J. (2017) Inelastic compaction and permeability evolution in volcanic rock. Solid Earth, 8, 561.

Faulkner, D.R., Sanchez-Roa, C., Boulton, C. and dem Hartog, S.A.M. (2018) Pore fluid pressure development in compacting fault gouge in theory, experiments, and nature. Journal of Geophysical Research: Solid Earth, 123, 226-241.

Friedlander, E.A. (2012) Nature and evolution of conduit faults in the 2004-2008 Mount St. Helens lava dome eruption. (Masters thesis). Vancouver, BC, Canada: University of British Columbia.

Gaunt, H.E., Sammonds, P.R., Meredith, P.G., Smith, R., and Pallister, J.S. (2014) Pathways for degassing during the lava dome eruption of Mount St. Helens 2004-2008. Geology, 42, 947-950.

Goto, A. (1999) A new model for volcanic earthquake at Unzen Volcano: Melt rupture model. Geophysical Research Letters, 26, 2541-2544.

Hale, A., and Wadge, G. (2008) The transition from endogenous to exogenous growth of lava domes with the development of shear bands. Journal of Volcanology and Geothermal Research, 171, 237-257.

Heap, M.J., and Kennedy, B.M. (2016) Exploring the scale-dependent permeability of fractured andesite. Earth and Planetary Science Letters, 447, 139-150.

Heap, M.J., Kolzenburg, S., Russell, J.K., Campbell, M.E., Welles, J., Farquharson, J.I., and Ryan, A.G. (2014a) Conditions and timescales for welding block-and-ash flow deposits. Journal of Volcanology and Geothermal Research, 289, 202-209.

Heap, M. J., Lavallée, Y., Petrakova, L., Baud, P., Reuschlé, T., Varley, N. R., and Dingwell, D. B. (2014b) Microstructural controls on the physical and mechanical properties of edificeforming andesites at Volcán de Colima, Mexico. Journal of Geophysical Research: Solid Earth, 119, 2925-2963.

Heap, M.J., Farquharson, J.I., Wadsworth, F.B., Kolzenburg, S., and Russell, J.K. (2015)

Timescales for permeability reduction and strength recovery in densifying magma. Earth and Planetary Science Letters, 429, 223-233.

Heap, M.J., Russell, J.K., and Kennedy, L.A. (2016) Mechanical behaviour of dacite from Mount St. Helens (USA): A link between porosity and lava dome extrusion mechanism (dome or spine)? Journal of Volcanology and Geothermal Research, 328, 159-177. 
Heap, M.J., Troll, V.R., Kushnir, A.R.L., Gilg, H.A., Collinson, A.S.D., Deegan, F.M., Darmawan, H., Seraphine, N., Neuberg, J., and Walter, T.R. (2019) Hydrothermal alteration of andesitic lava domes can lead to explosive volcanic behaviour. Nature Communications, 10, 5063.

Heap, M.J., Villeneuve, M., Albino, F., Farquharson, J.I., Brothelande, E., Amelung, F., Got, J.L., and Baud, P. (2020) Towards more realistic values of elastic moduli for volcano modelling. Journal of Volcanology and Geothermal Research, 390, 106684.

Heath, J.P. (1959) Dating Chaos Jumbles, an avalanche-deposit in Lassen Volcanic National Park. American Journal of Science, 257, 537-538.

Heiken, G., and Eichelberger, J.C. (1980) Eruptions at Chaos Crags, Lassen Volcanic National Park, California. Journal of Volcanology and Geothermal Research, 7, 443-481.

Holland, A.S.P., Watson, I.M., Phillips, J.C., Caricchi, L., and Dalton, M.P. (2011) Degassing processes during lava dome growth: Insights from Santiaguito lava dome, Guatemala. Journal of Volcanology and Geothermal Research, 202, 153-166.

Hornby, A.J., Kendrick, J. E., Lamb, O.D., Hirose, T., De Angelis, S., von Aulock, F.W., Umakoshi, K., Miwa, T., De Angelis, S.H., Wadsworth, F.B., Hess, K.-U., Dingwell, D.B., and Lavallée, Y. (2015) Spine growth and seismogenic faulting at Mt. Unzen, Japan. Journal of Geophysical Research: Solid Earth, 120, 4034-4054.

Horwell, C.J., Williamson, B.J., Llewellin, E.W., Damby, D.E., and Le Blond, J.S. (2013) The nature and formation of cristobalite at the Soufrière Hills volcano, Montserrat: implications for the petrology and stability of silicic lava domes. Bulletin of Volcanology, 75, 696.

Husain, T., Elsworth, D., Voight, B., Mattioli, G., and Jansma, P. (2014) Influence of extrusion rate and magma rheology on the growth of lava domes: Insights from particle-dynamics modeling. Journal of Volcanology and Geothermal Research, 285, 100-117.

Iverson, R.M., Dzurisin D., Gardner, C.A., Gerlach, T.M., LaHusen, R.G., Lisowiski, M., Major, J.J., Malone, S.D., Messerich, J.A., Moran, S.C., Pallister, J.S., Qamar, A.I., Schilling, S.P., and Vallance, J.W. (2006) Dynamics of seismogenic volcanic extrusion at Mount St. Helens in 2004-05. Nature, 444, 439-443

Kendrick, J.E., Lavallée, Y., Ferk, A., Perugini, D., Leonhardt, R., and Dingwell, D.B. (2012) Extreme frictional processes in the volcanic conduit of Mount St. Helens (USA) during the 2004-2008 eruption. Journal of Structural Geology, 38, 61-76. 
Kendrick, J.E., Lavallée, Y., Hirose, T., Di Toro, G., De Angelis, S., and Dingwell, D.B. (2014) Volcanic drumbeat seismicity caused by stick-slip motion and magmatic frictional melting. Nature Geoscience, 7, 438-442.

Kennedy, L.A., and Russell, J.K. (2012) Cataclastic production of volcanic ash at Mount Saint Helens. Physics and Chemistry of the Earth, 45, 40-49.

Kennedy, L.A., Russell, J.K., and Nelles, E. (2009) Origins of Mount St. Helens cataclasites: Experimental insights. American Mineralogist, 94, 995-1004.

Kolzenburg, S., Ryan, A.G., and Russell, J.K. (2019) Permeability evolution during nonisothermal compaction in volcanic conduits and tuffisite veins: Implications for pressure monitoring of volcanic edifices. Earth and Planetary Science Letters, 527, 115783.

Lamb, O.D., De Angelis, S., Umakoshi, K., Hornby, A.J., Kendrick, J.E., and Lavallée, Y. (2015) Repetitive fracturing during spine extrusion at Unzen volcano, Japan. Solid Earth, 6, 1277-1293.

Lavallée, Y., Benson, P.M., Heap, M.J., Hess, K.-U., Flaws, A., Schillinger, B., Meredith, P.G., and Dingwell, D.B. (2013) Reconstructing magma failure and the degassing network of dome-building eruptions. Geology, 41, 515-518.

Lavallée, Y., Hirose, T., Kendrick, J.E., De Angelis, S., Petrakova, L., Hornby, A.J., and Dingwell, D.B. (2014) A frictional law for volcanic ash gouge. Earth and Planetary Science Letters, 400, 177-183.

Loughlin, S.C., Luckett, R., Ryan, G., Christopher, T., Hards, V., De Angelis, S., Jones, L., and Strutt, M. (2010) An overview of lava dome evolution, dome collapse and cyclicity at Soufrière Hills Volcano, Montserrat, 2005-2007. Geophysical Research Letters, 37, L00E16.

Marone, C., Raleigh, C.B., and Scholz, C.H. (1990) Frictional behavior and constitutive modeling of simulated fault gouge. Journal of Geophysical Research, 95, 7007-7025.

Melnik, O., and Sparks, R.S.J. (2002) Dynamics of magma ascent and lava extrusion at Soufrière Hills Volcano. In T.H. Druitt, B.R. Kokelaar, Eds. The Eruption of Soufrière Hills Volcano, Montserrat from 1995-1999. Geological Society of London Memoirs 21, p. 153171.

Moore, P.L., Iverson, N.P., and Iverson, R.M. (2008) Frictional properties of the Mount St. Helens Gouge. In D.R. Sherrod, W.E. Scott, and P.H. Stauffer, Eds., A Volcano Rekindled: 
The Renewed Eruption of Mount St. Helens, 2004-2006. U.S. Geological Survey Professional Paper 1750, p. 415-424.

Moran, S.C., Malone, S.D., Qamar, A.I., Thelen, W.A., Wright, A.K., and Caplan-Auerbach, J. (2008) Seismicity associated with renewed dome building at Mount St. Helens, 2004-2005. In D.R. Sherrod, W.E. Scott, and P.H. Stauffer, Eds., A Volcano Rekindled: The Renewed Eruption of Mount St. Helens, 2004-2006. U.S. Geological Survey Professional Paper 1750, p. 27-60.

Muffler, L.J.P., and Clynne, M.A. (2015) Geological field-trip guide to Lassen Volcanic National Park and vicinity. U.S. Geological Survey Scientific Investigations Report 20155067, $67 \mathrm{p}$.

Nakada, S., Miyake, Y., Sato, H., Oshima, O., and Fujinawa, A. (1995a) Endogenous growth of dacite dome at Unzen volcano (Japan), 1993-1994. Geology, 23, 157-160.

Nakada, S., Motomura, Y., and Shimizu, H. (1995b) Manner of magma ascent at Unzen Volcano (Japan). Geophysical Research Letters, 22, 567-570.

Nakada, S., Shimizu, H., and Ohta, K. (1999) Overview of the 1990-1995 eruption at Unzen Volcano. Journal of Volcanology and Geothermal Research, 89, 1-22.

Neuberg, J.W., Tuffen, H., Collier, L., Green, D., Powell, T., and Dingwell, D.B. (2006) The trigger mechanism for low-frequency earthquakes at Montserrat. Journal of Volcanology and Geothermal Research, 153, 37-50.

Norton, G.E., Watts, R.B., Voight, B., Mattioli, G.S., Herd, R.A., Young, S.R., Devine, G.E., Aspinall, W.P., Bonadonna, C., Baptie, B.J., Edmonds, M., Jolly, A.D., Loughlin, S.C., Luckett, R. and Sparks, S.J. (2002) Pyroclastic flow and explosive activity at Soufrière Hills Volcano, Montserrat, during a period of virtually no magma extrusion (March 1998 to November 1999) In T.H. Druitt, B.R. Kokelaar, Eds. The Eruption of Soufrière Hills Volcano, Montserrat from 1995-1999. Geological Society Memoir 21, 467-481.

Okumura, S., and Kozono, T. (2017) Silicic lava effusion controlled by the transition from viscous magma flow to friction controlled flow. Geophysical Research Letters, 44, 36083614.

Okumura, S., and Sasaki, O. (2014) Permeability reduction of fractured rhyolite in volcanic conduits and its control on eruption cyclicity. Geology, 42, 843-846. 
Okumura, S., Uesugi, K., Nakamura, M., and Sasaki, O. (2015) Rheological transitions in hightemperature volcanic fault zones. Journal of Geophysical Research: Solid Earth, 120, 29742987.

Okumura, S., Kushnir, A.R.L., Martel, C., Champallier, R., Thibault, Q., and Takeuchi, S. (2016) Rheology of crystal-bearing natural magmas: Torsional deformation experiments at $800{ }^{\circ} \mathrm{C}$ and 100 MPa. Journal of Volcanology and Geothermal Research, 328, 237-246.

Pallister, J.S., Thornber, C.R., Cashman, K.V., Clynne, M.A., Lowers, H.A., Mandeville, C.W., Brownfield, I.K., and Meeker, G.P. (2008) Petrology of the 2004-2006 Mount St. Helens lava dome - implication for magmatic plumbing and eruption triggering. In D.R. Sherrod, W.E. Scott, and P.H. Stauffer, Eds., A Volcano Rekindled: The Renewed Eruption of Mount St. Helens, 2004-2006. U.S. Geological Survey Professional Paper 1750, p. 647702.

Pallister, J.S., Cashman, K.V., Hagstrum, J.T., Beeler, N.M., Moran, S.C., and Denlinger, R.P. (2013) Faulting within the Mount St. Helens conduit and implications for volcanic earthquakes. GSA Bulletin, 125, 359-376.

Quane, S.L., Russell, J.K., and Friedlander, E.A. (2009) Time scales of compaction in volcanic systems. Geology, 37, 471-474.

Quinn, E.T. (2014) Experimental determination of pre-eruptive storage conditions and continuous decompression of rhyodacite magma erupted from Chaos Crags, Lassen Volcanic Center, California (Masters thesis). Humboldt, CA, USA: Humboldt State University.

Rahaman, M.N. (2003) Ceramic Processing and Sintering, 875 p. Marcel Dekker Inc., New York, NY.

Raudsepp, M., Pani, E., and Dipple, G.M. (1999) Measuring mineral abundance in skarn. I. The Rietveld method using X-ray powder diffraction data. Canadian Mineralogist, 37, 1-15.

Rhodes, E., Kennedy, B.M., Lavallée, Y., Hornby, A., Edwards, M., and Chigna, G. (2018) Textural insights into the evolving lava dome cycles at Santiaguito lava dome, Guatemala. Frontiers in Earth Science, 6, 30.

Rose, W.I. (1972) Santiaguito Volcanic Dome, Guatemala. Geological Society of America Bulletin, 83, 1413-1434. 
Rowe, M.C., Thornber, C.R., and Kent, A.J.R. (2008) Identification and evolution of the juvenile component in 2004-2005 Mount St. Helens ash. In D.R. Sherrod, W.E. Scott, and P.H. Stauffer, Eds., A Volcano Rekindled: The Renewed Eruption of Mount St. Helens, 20042006. U.S. Geological Survey Professional Paper 1750, p. 629-646.

Rust, A.C., Cashman, K.V., and Wallace, P.J. (2004) Magma degassing buffered by vapor flow through brecciated conduit margins. Geology, 32, 349-352.

Rutherford, M.J. (2008) Magma Ascent Rates. Reviews in Mineralogy and Geochemistry, 69, 241-271.

Ryan, G.A., Loughlin, S.C., James, M.R., Jones, L.D., Calder, E.S., Christopher, T., Strutt, M.H., and Wadge, G. (2010) Growth of the lava dome and extrusion rates at Soufrière Hills Volcano, Montserrat, West Indies: 2005-2008. Geophysical Research Letters, 37, L00E08.

Ryan, A.G., Friedlander, E.A., Russell, J.K., Heap, M.J., and Kennedy, L.A. (2018a) Hot pressing in conduit faults during lava dome extrusion: Insights from Mount St. Helens 2004-2008. Earth and Planetary Science Letters, 482, 171-180.

Ryan, A.G., Russell, J.K., and Heap, M.J. (2018) Rapid solid-state sintering in volcanic systems. American Mineralogist, 103, 2028-2031.

Ryan, A.G., Russell, J.K., Heap, M.J., Zimmerman, M.E., and Wadsworth, F.B. (unpublished results) Timescales of porosity and permeability loss by solid-state sintering. Earth and Planetary Science Letters.

Samuelson, J., Marone, C., Voight, B., and Elsworth, D. (2008) Laboratory investigation of the frictional behavior of granular volcanic material. Journal of Volcanology and Geothermal Research, 173, 265-279.

Schneider, A., Rempel, A.W. and Cashman, K.V. (2012) Conduit degassing and thermal controls on eruption styles at Mount St. Helens. Earth and Planetary Science Letters, 357-358, 347354.

Schneider, D.J., Vallance, J.W., Wessels, R.L., Logan, M., and Ramsey, M.S. (2008) Use of thermal infrared imaging for monitoring renewed dome growth at Mount St. Helens, 2004. In D.R. Sherrod, W.E. Scott, and P.H. Stauffer, Eds., A Volcano Rekindled: The Renewed Eruption of Mount St. Helens, 2004-2006. U.S. Geological Survey Professional Paper 1750, p. 347-359. 
Scott, W.E., Sherrod, D.R., and Gardner, C.A. (2008) Overview of the 2004 to 2006, and continuing, eruption of Mount St. Helens, Washington. In D.R. Sherrod, W.E. Scott, and P.H. Stauffer, Eds., A Volcano Rekindled: The Renewed Eruption of Mount St. Helens, 2004-2006. U.S. Geological Survey Professional Paper 1750, p. 3-22.

Scruggs, M.A., and Putirka, K.D. (2018) Eruption triggering by partial crystallization of mafic enclaves at Chaos Crags, Lassen Volcanic Center, California. American Mineralogist, 103, 1575-1590.

Smith, R., Sammonds, P.R., Tuffen, H., and Meredith, P.G. (2011) Evolution of the mechanics of the 2004-2008 Mt. St. Helens lava dome with time and temperature. Earth and Planetary Science Letters, 307, 191-200

Sparks, R.S.J., Murphy, M.D., Lejeune, A.M., Watts, R.B., Barclay, J., and Young, S.R. (2000) Control on the emplacement of the andesite lava dome of the Soufrière Hills volcano, Montserrat by degassing-induced crystallization. Terra Nova, 12, 14-20.

Sparks, R.S.J. (1997) Causes and consequences of pressurisation in lava dome eruptions. Earth and Planetary Science Letters, 150, 177-189.

Tepley, F.J., Davidson, J.P., and Clynne, M.A. (1999) Magmatic interactions as recorded in plagioclase phenocrysts of Chaos Crags, Lassen Volcanic Center, California. Journal of Petrology, 40, 787-806.

Thelen, W.A., Crosson, R.S., and Creager, K.C. (2008) Absolute and relative locations of earthquakes at Mount St. Helens, Washington, using continuous data: implications for magmatic processes. In D.R. Sherrod, W.E. Scott, and P.H. Stauffer, Eds., A Volcano Rekindled: The Renewed Eruption of Mount St. Helens, 2004-2006. U.S. Geological Survey Professional Paper 1750, p. 71-95.

Tuffen, H., and Dingwell, D.B. (2005) Fault textures in volcanic conduits: evidence for seismic trigger mechanisms during silicic eruptions. Bulletin of Volcanology, 67, 370-387.

Underwood, S.J., Feeley, T.C., and Clynne, M.A. (2012) Hydrogen isotope investigations of amphibole and biotite phenocrysts in silicic magmas erupted at Lassen Volcanic Center, California. Journal of Volcanology and Geothermal Research, 227-228, 32-49.

Vallance, J.W., Schneider, D.J., and Schilling, S.P. (2008) Growth of the 2004-2006 lava-dome complex at Mount St. Helens, Washington. In D.R. Sherrod, W.E. Scott, and P.H. Stauffer, 
Eds., A Volcano Rekindled: The Renewed Eruption of Mount St. Helens, 2004-2006. U.S. Geological Survey Professional Paper 1750, p. 169-208.

Vasseur, J., Wadsworth, F.B., Lavallée, Y., Hess, K.-U., and Dingwell, D.B. (2013) Volcanic sintering: Timescales of viscous densification and strength recovery. Geophysical Research Letters, 40, 5658-5664.

Voight, B., Sparks, R.S.J., Miller, A.D., Stewart, R.C., Hoblitt, R.P., Clarke, A., Ewart, J., Aspinall, W.P., Baptie, B., Calder, E.S., Cole, P., Druitt, T.G., Hartford, C., Herd, R.A., Jackson, P., Lejeune, A.M., Lockhart, A.B., Loughlin, S.C., Luckett, R., Lynch, L., Norton, G.E., Robertson, R., Watson, I.M., Watts, R., and Young, S.R. (1999) Magma flow instability and cyclic activity at Soufrière Hills Volcano, Montserrat, British West Indies. Science, 283, 1138-1142.

Wadsworth, F.B. Vasseur, J., Scheu, B., Kendrick, J.E., Lavallée, Y., and Dingwell, D.B (2016) Universal scaling of fluid permeability during volcanic welding and sediment diagenesis. Geology, 44, 219-222.

Wadsworth, F.B., Vasseur, J., Llewellin, E.W., and Dingwell, D.B. (2017) Sintering of polydisperse viscous droplets. Physical Review E, 95, 033114.

Wallace, P.A., Kendrick, J.E., Miwa, T., Ashworth, J.D., Coats, R., Utley, J.E.P., De Angelis, S.H., Mariani, E., Biggin, A., Kendrick, R., Nakada, S., Matsushima, T., and Lavallée, Y. (2019a) Petrological architecture of a magmatic shear zone: A multidisciplinary investigation of strain localisation during magma ascent at Unzen Volcano, Japan. Journal of Petrology, 60, 791-826.

Wallace, P.A., De Angelis, S.H., Hornby, A.J., Kendrick, J.E., Clesham, S., von Aulock, F.W., Hughes, A., Utley, J.E.P., Hirose, T., Dingwell, D.B., and Lavallée, Y. (2019b) Frictional melt homogenisation during fault slip: Geochemical, textural and rheological fingerprints. Geochimica et Cosmochimica Acta, 255, 265-288.

Watts, R.B., Herd, R.A., Sparks, R.S.J. and Young, S.R. (2002) Growth patterns and emplacement of the andesitic lava dome at Soufrière Hills volcano. In T.H. Druitt, B.R. Kokelaar, Eds. The Eruption of Soufrière Hills Volcano, Montserrat from 1995-1999. Geological Society of London Memoirs 21, p. 115-152.

Watts, R.B., Clynne, M.A., Sparks, R.S.J., and Christiansen, R.L. (2013) The sequential emplacement of the Chaos Crags dome complex in Lassen Volcanic National Park and a 
subsequent avalanche event revealing the internal structure of a crystal-rich lava dome. AGU General Assembly, San Francisco, California, US, 9-13 December, V13G-2707. Wright, H.M.N., and Cashman, K.V. (2014) Compaction and gas loss in welded pyroclastic deposits as revealed by porosity, permeability and electrical conductivity measurements of the Shevlin Park Tuff. GSA Bulletin, 126, 234-247.

Wright, H.M.N., Lesti, C., Cas, R.A.F., Porreca, M., Viramonte, J.G., Folkes, C.B., and Giordano, G. (2011) Columnar jointing in vapor-phse-altered, non-welded Cerro Galan Ignimbrite, Paycuqui, Argentina. Bulletin of Volcanology, 73, 1567-1582.

Yund, R.A., Blanpied, M.L., Tullis, T.E., and Weeks, J.D. (1990) Amorphous material in high strain experimental fault gouges. Journal of Geophysical Research, 95, 15589-15602.

Zhu, W., Evans, B., and Bernabé, Y. (1999) Densification and permeability reduction in hotpressed calcite: A kinetic model. Journal of Geophysical Research, 104, 25501-25511.

Zorn, E.U., Rowe, M.C., Cronin, S.J., Ryan, A.G., Kennedy, L.A., and Russell, J.K. (2018) Influence of porosity and groundmass crystallinity on dome rock strength: a case study from Mt. Taranaki, New Zealand. Bulletin of Volcanology, 80, 35. 


\section{Figure Captions}

Figure 1: Chaos Crags, Lassen Volcanic Center, California (USA). Chaos Crags consists of six rhyodacitic domes (from oldest to youngest: Domes A to F). Dome C partially collapsed $\sim 350$ years ago to form the Chaos Jumbles deposit. Camera elevation $6.6 \mathrm{~km}$ (Google Earth, (c) 2020 Google).

Figure 2: Field photographs of Chaos Crags study site on Dome C at different scales: (a) Exposed face of Dome $\mathrm{C}$, looking SE, showing the interior of lava dome and the shear zone, including a fault gouge (G), between the massive dacite lava (D) and the older andesitic wall rocks (WR) on SW margin. Photo credit: S. Kolzenburg. Black arrow shows orientation and location of next photo. (b) Photograph, looking N, of outcrop of preserved shear zone outlined in black box and enlarged in (c,d); black arrow shows orientation and location of next photo. (c,d) This outcrop exposes the larger structural organization of the shear zone from close to the dome interior (left) to the edge of the preserved shear zone (dashed line). Black stars show same feature in both photos. Shear zone consists of a pink dacite breccia (DB), high-porosity, pink cataclasite $\left(\mathrm{C}_{\mathrm{Hi}}\right)$ containing bands of low-porosity, dark red to brown cataclasite $\left(\mathrm{C}_{\mathrm{Lo}}\right)$. Black box in $(\mathrm{d})$ shows the location of the next photo. (e) Band of $\mathrm{C}_{\mathrm{Lo}}$ containing fractured and sheared plagioclase grains. Contact with $\mathrm{C}_{\mathrm{Hi}}$ can be sharp (right side of (e)) or gradational (left side of (e)). (f) Lower panel shows representation of transition from lava dome to shear zone to conduit wall and sample locations.

\section{Figure 3: Plain polarized light (PPL) photomicrographs and backscatter electron (BSE)} images of units from Dome C. (a,b,c) Undeformed dacite (D) showing groundmass texture and porosity distribution. Patches of cristobalite (cr) and phenocrysts of plagioclase (pl) are labelled in (b). Acicular crystals are apparent in (c). (d,e,f) Highporosity cataclasite $\left(\mathrm{C}_{\mathrm{Hi}}\right)$. The groundmass of $\mathrm{D}$ and matrix of $\mathrm{C}_{\mathrm{Hi}}$ look similar in PPL (d) but are distinguishable in SEM images (e,f). $\mathrm{C}_{\mathrm{Hi}}$ shows blocky and subrounded clasts joined by necks of material (examples shown with yellow arrows in (f)) and a high proportion of interconnected, irregularly shaped intergranular porosity. Clasts of plagioclase (pl) or a silica polymorph (si) are labelled in (e). (g,h,i) Low-porosity cataclasite $\left(\mathrm{C}_{\mathrm{LO}}\right)$. Matrix is dark brown to dark grey in PPL. SEM shows little residual 
porosity and an increased proportion of coalesced clasts, some of which still show necks of crystalline material (yellow arrows in (i)).

Figure 4: PPL and BSE images of textural features in cataclasites. (a) $\mathrm{C}_{\mathrm{Hi}}$ and $\mathrm{C}_{\mathrm{Lo}}$ containing lenses of shattered, sheared plagioclase grains. White box shows location of (b). (b) Plagioclase lenses are high porosity relative to surrounding $\mathrm{C}_{\mathrm{Lo}}$, and contain angular fragments that have not been significantly displaced. (c) $\mathrm{C}_{\mathrm{Hi}}$ containing a diffuse patch of $\mathrm{C}_{\mathrm{Lo}}$ (color difference in lower left quadrant) and a sheared mafic inclusion (through middle of photomicrograph; indicated in thin section by an abundance of juxtaposed small, subangular plagioclase and oxidized amphiboles microphenocrysts). A shattered and sheared single plagioclase grain is above the image - its "tail" extends into image (dashed line). White box shows location of (d). (d) SEM image shows very low porosity of sheared mafic inclusion relative to surrounding cataclasite. (e) Rounded clast of $\mathrm{C}_{\mathrm{Lo}}$ within $\mathrm{C}_{\mathrm{Hi}}$. Segments of dashed line define portions of clast edge. (f) Contact between rounded, low-porosity $\mathrm{C}_{\mathrm{Lo}}$ clast and high-porosity $\mathrm{C}_{\mathrm{Hi}}$ matrix.

Figure 5: Connected porosity and permeability. Measured permeability $(k)$ against connected porosity $\left(\phi_{c}\right)$ for cores from samples of the cataclasite units (circles) and the dacite (diamonds). $\mathrm{C}_{\mathrm{Lo}}$ and $\mathrm{C}_{\mathrm{Hi}}$ occupy distinct regions in $\phi_{c}-k$ space. Also plotted, the monodisperse permeability model of Wadsworth et al. (2016) (particle radius $=10 \mu \mathrm{m}$ ). Data for cataclastic materials (circles) scatter along the model curve.

Figure 6: Distribution of porosity, permeability and strength across Dome $\mathbf{C}$ units. (a) Schematic summary of textural zonation of shear zone and relative sample locations. $(\mathbf{b}, \mathbf{c})$ Total porosity $\left(\phi_{t}\right)$ and permeability $(k)$ of units measured on cores oriented parallel (along z-axis; open circles) and perpendicular (along x-axis; filled circles) to the extrusion direction. $\phi_{c}$ and $k$ are lowest in $\mathrm{C}_{\mathrm{Lo}}$ and increase towards the edge of shear zone $\left(\mathrm{C}_{\mathrm{Hi}}\right.$ to $\left.\mathrm{G}\right)$. Cores oriented along the $\mathrm{x}$-axis are weakly less porous and permeable than cores oriented along the z-axis. (d) Measured uniaxial compressive strength $(U C S) . \mathrm{C}_{\mathrm{Lo}}$ is the strongest unit. Strength decreases across the shear zone. (e) 
Young's modulus $(E) . \mathrm{C}_{\mathrm{Lo}}$ is the stiffest unit in the shear zone. Gouge properties are inferred (see text).

Figure 7: Sintering time and ascent rate modelling. (a) Modelled range of compressive pressures the gouge experiences over $1 \mathrm{~km}$ depth. $P_{\min }$ is the lithostat (dotted) and $P_{\max }$ is a best-fit line for the compressive strength of the dacite as a function of depth (solid). Experimental data are plotted: open circles are $P_{\text {eff }}$ for the corresponding measured strength (filled circles), connected by dashed tie-lines (Table 5). See Supplement S2 for details. (b) Change in total porosity with time (days; contours) plotted against depth for $P_{\min }$ (dotted curves) or $P_{\max }$ (solid curves). Shaded fields are the porosities of units $\mathrm{G}, \mathrm{C}_{\mathrm{Hi}}$ and $\mathrm{C}_{\mathrm{Lo}}$. Model curves are not extended past 0.05 as at low porosities sintering dynamics change (Wadsworth et al., 2017). (c) Minimum time needed to sinter gouge to form cataclasites with total porosities measured in units $\mathrm{C}_{\mathrm{Hi}}$ ( $\left.\phi_{t}=0.20\right)$ and $\mathrm{C}_{\mathrm{Lo}}\left(\phi_{t}=0.08\right)$, against depth (dashed curves). Modelled linear ascent rates $\left(\mathrm{m} / \mathrm{d}\right.$; solid curves) $<10 \mathrm{~m} / \mathrm{d}$ pass through the "sintering window" for $\mathrm{C}_{\mathrm{Lo}}$ (dark grey region).

Figure 8: Effects of evolving shear zone strength and permeability on lava dome eruptions. (a) Shear zone (SZ) permeability (black curve) and strength (grey curve) relative to the solidifying magma plug $(M$; where $y=1)$. Fracturing (black star) of the margins of the plug initiates cataclasis and the formation of the gouge-filled shear zone. Vertical boxes correspond to snapshots (b-f). A second cycle of cataclasis and sintering occurs following a second fracturing event (black star in vertical box e). (b) Initial shear zone, comprised of unconsolidated gouge (dotted region) with a frictional shear resistance $\left(F_{S Z}\right)$ less than plug strength $\left(\sigma_{M}\right)$. Magma plug can easily advance (black half arrows; length $\sim$ ease of shear deformation). Also, shear zone permeability $\left(k_{S Z}\right)$ is greater than magma permeability $\left(k_{M}\right)$ (grey arrows; size $\sim$ permeability) and transmits gaseous volatiles (grey curves). (c) With time, shear zone comprises a permeable cataclasite (light grey region) with a shear strength $\left(\sigma_{S Z}\right)$ less than $\sigma_{M}$. (d) With increasing time the cataclasite becomes stronger and less permeable than the magma (e.g., $\mathrm{C}_{\mathrm{L} \text {; }}$; dark grey region). The plug stalls and pore pressures below the magma increase (shaded 
region). (e) Shear zone fractures, causing the explosive release of trapped volatiles. Fracturing initiates another cycle of gouge-generation (i.e., shearing, grain size reduction and compaction). (f) The gouge-filled shear zone can undergo another cycle of sintering. 


\section{Declaration of interests}

$\bigotimes$ The authors declare that they have no known competing financial interests or personal relationships that could have appeared to influence the work reported in this paper.

$\square$ The authors declare the following financial interests/personal relationships which may be considered as potential competing interests: 
CRediT author statement

Amy Ryan: Conceptualization, Investigation, Formal Analysis, Writing-Original Draft, Writing-

Review and Editing, Visualization. Michael Heap: Conceptualization, Investigation, Writing-

Review and Editing. Kelly Russell: Conceptualization, Writing-Review and Editing,

Supervison. Lori Kennedy: Resources, Writing-Review and Editing. Michael Clynne:

Resources, Writing-Review and Editing. 


\section{Highlights:}

- A syn-eruptive shear zone (gouge and cataclasites) envelopes Dome $\mathrm{C}$ at Chaos Crags

- Shear zone cataclasites have lost porosity and lithified by solid-state sintering

- Magma ascent rates $<10 \mathrm{~m} / \mathrm{d}$ are required to form observed cataclasites

- Shear zone permeability loss and strengthening hinder outgassing and magma ascent

- Cyclic fracturing and sintering can dictate lava extrusion vs. explosivity 